\title{
Competing with kreteks: transnational tobacco companies, globalisation, and Indonesia
}

\author{
S Lawrence, J Collin
}

Tobacco Control 2004;13(Suppl II):ii96-ii103. doi: 10.1136/tc.2004.009340

See end of article for authors' affiliations

.....................

Correspondence to: Ms Sue Lawrence, Centre on Global Change and Health, London School of Hygiene and Tropical Medicine, Keppel Street, London WClE 7HT, UK; sue.lawrence@lshtm.ac.uk

\begin{abstract}
Objective: To examine the strategies employed by transnational tobacco companies (TTCs) to compete more effectively compete with the dominant kretek manufacturers in Indonesia, and to consider implications of their failure.

Methods: Systematic analysis of corporate documents obtained from British American Tobacco's (BAT's) Guildford depository and from industry and tobacco control websites document collections.

Results: The limited progress of the TTCs in Indonesia is best explained by the distinctive political economy of its tobacco industry. Though effective when collaborating on regulatory issues of mutual interest, TTCs have been less able than kretek manufacturers to exercise political influence where their interests conflict. Global strategies of TTCs have undergone significant local adaptation in attempting to compete in this distinctive environment. While maintaining uniformity in core brand attributes, TTCs have sought to reconcile international imagery with local norms, particularly to appeal to women. BAT unsuccessfully attempted to develop clove based products that imitated the appeal of kreteks, withdrawn following concerns about exposing the company to charges of operating double standards.

Conclusions: The documents presented highlight the complexity of the global tobacco industry. Tobacco control efforts need to address more effectively the ongoing impact of kreteks while recognising the distinctive threats posed by TTCs.
\end{abstract}

$\mathrm{T}$ he escalating scale and shifting distribution of the tobacco pandemic ${ }^{1-3}$ are increasingly being interpreted with reference to the globalisation of the tobacco industry. ${ }^{4-6}$ Such accounts frequently highlight the role of transnational tobacco companies (TTCs) as the "primary vectors" of this pandemic. ${ }^{7}$ This label recognises the increasing reliance of TTCs on emerging markets, particularly across Asia and central and eastern Europe, ${ }^{8}$ where opportunities presented by changes in the global economy have been exploited via aggressive programmes of mergers, acquisitions, and joint ventures. ${ }^{9-12}$ TTCs are seen as able to increase tobacco consumption more effectively than smaller domestic companies, particularly state monopolies, with their entry into new markets constituting a distinctive threat to public health. ${ }^{13}{ }^{14}$ Understanding their strategies therefore constitutes a precondition for the development of effective tobacco control policy..$^{15} 16$

This status of TTCs as a principal threat to global health is well grounded, but should not be misconstrued as implying that their rise is inexorable or that a uniform global dominance is inevitable. It is possible to exaggerate their power and impact, as in assertions that their marketing strategies simply override cultural differences across populations ${ }^{17}$ and that other forms of tobacco consumption such as bidis and pan masala are being reduced to marginal ancient customs. ${ }^{12}$

Indonesia provides a particularly important and instructive case study in the limitations of a simplified image of the global tobacco industry. Progress in the enormous Indonesian market represents a long held ambition for TTCs. As yet, however, they are far from dominant and indeed their market share has undergone rapid decline in recent decades. This article explores the diverse strategies employed by TTCs in Indonesia, focusing particularly on the efforts of BAT Indonesia (BATI) to adapt to a unique competitive environment.

\section{METHODOLOGY}

Document research for this paper was primarily conducted at the Guildford depository. Iterative searching of the depository's file-level index, commencing with geographical terms (for example, Asia-Pacific, Indonesi*, Java) and kretek. Subsequent searching focused on relevant organisational structures, projects and key personnel (for example, Asia Pacific RBU, BAT Indonesia, BATIK, P Adams, J Priem, C Jenkins, A Heard). This was supplemented by complementary searching of documents from Philip Morris (PM) and RJ Reynolds (RJR) via company operated websites and the University of California San Francisco (UCSF) Legacy and Tobacco Documents Online collections websites. The protracted nature of the dispute required the examination of BAT documents made available at the Minnesota depository through ongoing litigation.

The broad advantages and difficulties entailed in working with tobacco industry document research have been previously described, ${ }^{18-21}$ while the more specific problems for research posed by BAT's operation of its Guildford document depository have recently been highlighted. ${ }^{22-24}$ Importantly, documents analysed during this research primarily originated as correspondence between company headquarters and regional offices. Litigation has not required the disclosure of documents held in the region, and the internal documents of kretek manufacturers are also inaccessible.

Secondary research included examination of existing academic literature on tobacco consumption in Indonesia, analyses of Indonesian politics and history, as well as newspapers and industry trade journals.

Abbreviations: BAT, British American Tobacco; BATI, BAT Indonesia; BPPC, Clove Support and Trading Board; IBs, international brands; PM, Philip Morris; TTCs, transnational tobacco companies; USIBs, international brands originating in the USS 


\section{RESULTS}

\section{Historical background}

TTCs have long identified the potential profitability of the Indonesia market given it was "the fourth most populous country in the world, the second largest cigarette market in Asia Pacific (including kreteks) and experiencing high growth" ${ }^{25}$ In the 1990s Indonesia experienced the world's highest increase in cigarette consumption of around $47 \%$ and by 1995 an estimated $68.8 \%$ of men and $2.6 \%$ of women smoked. ${ }^{27}$ Yet, in contrast to the successful expansion of the TTCs both globally and elsewhere in south east Asia, the 1990s represented a decade of failure in Indonesia.

An explanation for this apparent paradox begins with the unique nature of the tobacco market and industry in Indonesia. Though there is a shortage of reliable market information, ${ }^{28}$ estimates suggest that only around one in 10 of the 240 billion cigarettes consumed annually are conventional white stick cigarettes ("whites"), with $88 \%$ accounted for by kreteks. ${ }^{29}{ }^{30}$ Incorporating diverse ingredients, kreteks are cigarettes based on a blend of tobacco with cloves and clove oil, lending them a distinctive scent. The anaesthetising effect of clove oil accounts for their historic use to alleviate sore throats and asthma but also results in high tar yields and potentially extensive lung damage. ${ }^{2} 3132$ The kretek's dominance reflects an enormous and diverse indigenous industry. Domestic giants led by Gudang Garum, Sampoerna, and Djarum, have market shares of around 38\%, 20\%, and 18\%, respectively, but the industry is remarkably fragmented and incorporates a substantial cottage industry. ${ }^{29}$

Despite the oft proclaimed status of the kretek as a key cultural signifier and powerful symbol of Indonesia, ${ }^{31}{ }^{33}$ their dominance is a comparatively recent phenomenon and white cigarettes have a long established presence. BAT's involvement began with the acquisition of a factory on Java in 1908. By 1930 annual output of kreteks was around 7 billion, while in Java BAT recorded sales of 4.8 billion in 1931..$^{34}$ Though wartime did much to establish the kretek industry at the expense of BAT, ${ }^{34}$ when PM established a joint venture in 1971 the annual total of white cigarette sales were equivalent to around four fifths of the kretek total and the gap was expected to narrow. ${ }^{36}$

PM's rationale for investment in Indonesia projected rapid expansion in demand for virginia and blended cigarettes, assuming that given rapid economic growth "the more affluent Indonesian consumer will seek higher quality cigarettes". ${ }^{36}$ Such confidence was understandable given trajectories elsewhere, and market share for white cigarettes reached $44 \%$ in $1980 .{ }^{28}$ Understanding their subsequent collapse requires an examination of the distinctive political economy of tobacco in Indonesia.

\section{Indonesia and tobacco politics}

Indonesian governments have been consistently supportive of the local tobacco industry, particularly under General Suharto's authoritarian regime. It enthusiastically anticipated increased consumption during the 1990s and in 1996 the health minister confirmed that "the government had no intention of trying to regulate smoking through legislation". ${ }^{32}$ A PM corporate affairs plan noted that the cigarette market "enjoys the protection of the Government in the form of favourable VAT rates". ${ }^{37}$

BAT's factories had been briefly seized during the nationalist presidency of Sukarno, ${ }^{28}$ and a more sympathetic attitude towards transnational investments was anticipated following the military coup of 1965-66. BAT reportedly attended a conference in Geneva in November 1967 whereby Suharto's economists and leading transnational corporations carved up the Indonesian economy sector by sector. ${ }^{38}$ Both BAT and PM favoured the comparative stability brought by
Suharto, ${ }^{39}$ with PM noting the "purge of Communist factions and the deaths of at least 300,000 Indonesians". ${ }^{36}$

The decline of white cigarettes is partly attributable to the complex regulatory peculiarities of the Indonesian economy from the late 1970s, as domestic companies were increasingly favoured by a regime enriched by oil boom capital. ${ }^{40} \mathrm{PM}$ found the environment extremely difficult, selling their Malang production facilities to Sampoerna in $1980 .{ }^{31}{ }^{41}$

The dominance of the kretek industry partly reflects its successful modernisation. The introduction of kretek rolling machines in the mid 1970s gave the large domestic companies an efficiency with which TTCs struggled to compete. $^{30} 3142$ A BATI business analysis in 1992 noted that "the presence of large and efficient Kretek manufacturers, with their attendant economies of scale, holds down prices overall, thereby squeezing the smaller companies such as $\mathrm{BAT}^{\prime \prime} \cdot{ }^{43}$

The strength of kretek manufacturers was, however, critically underpinned by their greater political influence within Indonesia more consistently and effectively than TTCs. This is attributable both to the industry's perceived economic significance and to the vested interests of key figures in Indonesian politics. It has been claimed that 10 million people are supported by the kretek industry and its supply chain in Indonesia, and governments have historically displayed a protectionist attitude to employment in the sector. $^{34}{ }^{42}$ A 1979 decree, for example, obliged each company to roll one kretek by hand for every two produced by machine. ${ }^{30}$

The kretek industry was indirectly assisted by broader policies of the Suharto regime, particularly the imposition of transmigration. This compulsory uprooting of communities from heavily populated regions such as Java, Madura, and Bali provided a demographic shift that enabled kretek manufacturers to expand across the entire archipelago. ${ }^{31}$ Additionally, the industry was well placed to exploit the endemic nepotism and corruption characteristic of the regime. ${ }^{44}$ In 1984 the founder of Gudang Garam, Surya Wonowidjojo, established a joint venture with Suharto's brother, Probosutedjo, to produce cigarette paper. $^{31}$ Notoriously, the General's son Tommy Suharto established the BPPC (Clove Support and Trading Board), and proceeded both to dramatically underpay clove farmers and horrifically mismanage the supply of cloves. Such mismanagement eventually led to the BPPC being disbanded under pressure from the International Monetary Fund in 1998. ${ }^{32} 4546$

\section{Kreteks and TTCs: mutual interests}

For TTCs, the privileged position of the kretek industry only becomes problematic when their respective interests diverge. On many regulatory issues they are natural allies and have cooperated closely via their respective peak associations, the union of kretek manufacturers GAPPRI (Gabungan Pengusaha Pabrik Rokok Indonesia) and the association of white cigarette producers GAPRINDO. An alliance between the two was formalised in 1991 with an agreement "to set up a joint action team to deal with S\&H (smoking and health) issues" be chaired by PT Djarum with PT BATI as secretary. ${ }^{47}$

The mutual value of such cooperation was demonstrated by their success in diluting regulations proposed by the Department of Health in 1992. The Department had been granted control over the "circulation, quality and production processes of cigarettes", enabling it to control "the extent of tar and nicotine contents of the tobacco material". ${ }^{48}$ Additionally, the Department sought the introduction of rotating health warnings on cigarette packs. $^{49}$ Dahlia Sardjono of BATI's public affairs team, noted that nicotine was likely to be classified as addictive while "cigarette sales will probably be controlled like other addictive substances i.e. 
drugs", with potential further regulation of advertising and smoking in public places. ${ }^{50}$ Subsequent draft legislation provided for withdrawal of products that failed to meet health standards and for ingredients labelling, and threatened to regulate tobacco as an addictive substance. ${ }^{51}$

BAT's head office supplemented and directed the lobbying efforts of BATI. Sharon Boyse, BAT's smoking and health issues manager, provided BATI with a clear line on what was acceptable regarding ingredient disclosure ${ }^{52}$; provided lobbying materials addressing addiction and environmental tobacco smoke ${ }^{49}$; planned a media briefing seminar; and travelled to Jakarta to lobby members of parliament..$^{53}$ BAT asserted that it had "an opinion worth listening to and one that reflects the views of international experts" ${ }^{53}$

The combined efforts of kretek and white cigarette manufacturers were apparently successful. Sardjono informed Boyse of the "good news" that legislation had been officially signed "about the safety use of addictive substances without further mentioning any particular substance i.e. nicotine".$^{54}$ BATI endorsed further collaboration between GAPPRI and GAPRINDO, recommending further joint efforts "to influence key decision takers". 55 A later assessment of the political capacity of the white cigarette industry by the Tobacco Institute of New Zealand noted:

"The industry is clearly capable of effectively lobbying government. It has succeeded in reducing a call for four rotating health warnings to a requirement for one non causal warning on the side of the pack... As I understand, the lobby on warnings involved mainly in the Health Minister, the Director General of Health and the Director of Food and Drug Control with support for the industry from the Director of Excise and the Director of Various Industries... (I)t is to the industry's advantage to build effective and continuing liasion with the ministeries of Finance, Industry, Trade and Horticulture together with the Co-ordinator-Economic and Finance. It is also clear that good intelligence is necessary on the input of the WHO to the Minister of Health. ${ }^{48}$

\section{Kreteks and TTCs: political competition}

By contrast, issues of pricing and taxation have been the source of persistent contest between kretek and white manufacturers since these lie at the core of their competition. Excise tax constitutes a critical issue in Indonesia since cigarette sales were expected to account for $94 \%$ of total excise revenue for 2003. ${ }^{56}$ Despite periodic fluctuations, domestic manufacturers have generally secured a tax regimen favouring kreteks, and this has been central to the long term decline of white stick cigarettes. BAT have long bemoaned their comparative lack of influence, claiming that Indonesia is "a corrupt society and BAT is unable to exert influence on officialdom in the manner open to local manufactures". ${ }^{57}$ Sustained attempts have been made to exert greater influence, a 1991 future business report promising "continuous lobbying and dialogue with Excise Office, both direct and through GAPRINDO" ${ }^{\prime 58}$ while excise reform was identified as a strategic priority for 1993-97. ${ }^{59} \mathrm{PM}$ Asia similarly outlined an action plan to achieve a switch to specific excise taxes:

Develop Government/legislative contact program Analyze the present structure of the Ministry of Finance and the taxation department and determine any relevant associations of these incumbents.
Commission tax study by Centre for Strategic and International Studies (CSIS) or another highly regarded consulting firm like Price Waterhouse. Use all the results of study to demonstrate benefits accruing to all manufacturers...

Seek support from leading economists in Indonesia to lend academic credence to our arguments.

Present studies to Ministry of Finance through appropriate intermediaries. ${ }^{37}$

While other issues such as constituent labelling and tar and nicotine levels have also been periodically central to the political contest between the industry's two branches, excise tax has consistently been the key battleground. The success of white manufacturers in securing a 1993 increase in excise taxes for kreteks ${ }^{60}$ was overturned by 1999 reforms that BATI greeted by threatening to end manufacturing in the country.

\section{Global brands: seeking converts}

TTCs have not simply regarded Indonesia as immune to broader global trends, particularly the rise of international brands (IBs). Significant efforts have been undertaken to encourage conversion or "upgrading" from kreteks. ${ }^{61}$ Attention has focused particularly on USIBs (international brands originating in the USA), with PM predictably seeking expansion via Marlboro brand and BAT heavily supporting Lucky Strike.

The very transnationality of the TTCs has frequently provided an important resource in their expansion among developing countries. ${ }^{6}$ The marketing of IBs has highlighted images of prosperity, modernity, internationality, and independence and linked USIBs with purportedly American values. ${ }^{62-64}$ Such imagery has been directed towards converting kretek smokers to IBs, often via sports sponsorship. A 1993 sponsorship appraisal of the Team Lucky Strike Suzuki motorcycle team, for example, noted that "the Lucky Strike sponsorship is driving the brand towards its target image" in Indonesia, identifying strong resonance with terms such as modern, masculine, freedom, and American values. ${ }^{65}$

BATI's local research into smokers of IBs explained their preference principally via such imagery, a byproduct being consistently favouring smuggled product:

The core smokers of International Brands are the better-off segment in the Indonesian society who have exposed themselves to modernity and progress through good education. This makes them tend to prefer brand (sic) with the Internationalism element (Even, they prefer the contraband, supposed to be "original from abroad"). ${ }^{66}$

This "Internationalism element" was addressed by the use of gold in Benson \& Hedges' advertising and packaging, while Lucky Strike's "An American Original" slogan effectively generated a link with the USA ("The smokers here are just like the smokers there", "As if we also belong to the advanced country"). ${ }^{65}$

Research conducted for PM in 1988 established that the perception of IBs as connoting a prosperous cosmopolitanism constituted a key resource in converting kretek smokers. Explanations of the occasions when "dual users" chose white sticks rather than kreteks included prestige, prosperity, and an alleged taste preference. Even the latter was attributed to the powerful symbolism of the IB:

The preference for white's taste is probably a claim of what they think they ought to prefer due to International White's more elite international imagery ${ }^{67}$ 
A disturbing feature of the attitudes identified by both BAT and PM is the belief that IBs constitutes a healthier alternative to kreteks. The BATI study of IB smokers found that one of the perceived advantages of smoking white cigarettes was that "it is less dangerous to health". ${ }^{65}$ Similarly, research conducted for PM suggested that male smokers regarded "Kretek as more dangerous because 'heavier"". ${ }^{66}$ Such responses echo the association of light or mild cigarettes with reduced risk, ${ }^{68}$ a link that is given potential competitive advantage via the higher tar and nicotine yields of kreteks. This has been the theme of recent press advertisements by BATI, ${ }^{69}$ and explains the enthusiasm of the white cigarette manufacturers for legislation reducing permitted yields. ${ }^{29}$

\section{"Glocalisation" and TTCs in Indonesia}

While IBs are increasingly promoted on an integrated global basis, Indonesia demonstrates that such promotion is far from uniform. While a globally coherent brand image requires consistency in its core elements, TTCs have recognised the commercial importance of adapting to local context. In a 1992 speech entitled "Think Global-Act Global-Adapt Local" BAT's head of marketing Jimmi Rembiszewski noted that effectively exploiting global trends required an acknowledgement of their limitations:

So you will find today that most international brands do have consistent advertising strategies and executions, pack designs and family line. But varying taste tailored to the local acceptance. One could sum it up to say that there are significant global convergence in all optical (habits and practice) brand areas but still strong local resistance to taste or internal convergence. ${ }^{70}$

A purely global strategy treating the world as an undifferentiated market is seen as unfeasible or undesirable. The importance of incorporating local adaptation suggests that BAT's overall strategy should be shaped by a worldwide perspective with its implementation varying according to local norms, preferences, regulations and competition. This might be better described as a "glocal" strategy. ${ }^{71} 72$ In 1989 Frank Resnik, the then chairman of PM USA, discussed the implications of "glocalization" for corporate strategy:

"It refers to ways of promoting world brands that are strategic globally, but that are also sensitive to the tastes and interests of different markets... Marlboro maintains the same packaging around the world. And Marlboro advertising is the same worldwide, from Hong Kong to Hamburg. We never depart from the image of the Marlboro cowboy and Marlboro country. At the same time, we supplement Marlboro's world image with marketspecific promotions like motor sports in France, horseback events in Latin America and badminton competitions in Indonesia and Malaysia" ${ }^{\prime 7}$

The emphasis on uniformity in core global attributes is particularly strong in connection with Marlboro, ${ }^{74}$ but Indonesia's regulatory environment required adaptation even of its distinctive imagery. Regulations prohibiting the use of "recognisably Caucasian persons" in commercials posed problems in depicting the Marlboro cowboy, resolved via reediting to "maintain an heroic attitude without distinguishing cowboys' faces". ${ }^{75}$ Such revision is by no means unprecedented, ${ }^{76}$ but a striking feature of the Indonesian documents is the breadth of adaptation attempted, particularly by BAT.
It is, however, important to recognise that the scope for such local adaptation was circumscribed. BATI initiatives that addressed issues of core concern to the wider group were rejected in clear assertions of central control over the local operating company. A booklet addressing smoking and health issues ${ }^{77}$ was ordered to be withdrawn since "virtually every paragraph in the booklet contains something totally contrary to our position and potentially very damaging" ${ }^{\prime 78} \mathrm{~A}$ proposed insurance fund against liability claims was similarly rejected to ensure "that the company retains full control of litigation in this area". ${ }^{79}$

\section{Promoting brands: reconciling the global and the local}

Adaptation in responding to local norms is exemplified by efforts to promote tobacco consumption among women. The cultural taboos that have heavily circumscribed smoking by women may be gradually shifting, ${ }^{80}$ but their ongoing relevance complicates the marketing task in Indonesia. A research proposal submitted to PM in 1988 noted that effective targeting of Indonesian women needed to acknowledge the divergent images evoked, but held the promise of significant gains:

As women are an important possible target, we feel we should point out that female smoking in Indonesia evokes two contrary perceptions. One is of modernity and sophistication, the other of disreputability (the bar-girl image). The latter is stronger the lower the socio-economic status... That is not to say that they are not a valid target. A correctly positioned brand may be able to increase smoking incidence as well as win share. ${ }^{81}$

Research subsequently confirmed the complexity of this marketing task. Among the views on women smoking expressed by existing female smokers were that it was "cheap" and gave a bad impression in public. While it was also held to be modern and impressive, the report noted that their perceptions of women smoking as emancipated, intellectual, and independent were "not totally positive assessments, even amongst these women" ${ }^{\prime 6}$ The commercial opportunity for TTCs was affirmed by the positive reactions of Indonesian women to Virginia Slims' packaging and advertising and by the preference of dual users for smoking white cigarettes "when 'prestige' requires (particularly for women)" $)^{\prime 66}$

The linkage of images of prosperity, modernity and frequently with the USA, was also viewed as potentially problematic in Indonesia. As in other predominantly Islamic states, TTCs have viewed religion as potentially significant to their local prospects. ${ }^{82}$ This can reflect a concern that smoking may be declared haram, forbidden, ${ }^{83}$ but in Indonesia the TTCs were concerned that the cultural background of the kretek industry might prove to be of competitive advantage. In 1979 BAT addressed the possible export of Indonesian kreteks:

\section{A possible sales campaign would be based on Kretek as the Muslim cigarette produced by, with and for Muslims, whereas the 'white' cigarette is the product of Infidel multinational corporations ${ }^{84}$}

An interesting postscript is provided by the 2003 launch of a kretek by Indonesia's largest Muslim organisation, the Nahdlatul Ulama. Named The Tali Jagat ("rope of the universe" ), this kretek was reportedly intended for promotion at mosques across the province. ${ }^{85}$

BATI recognised the need to reconcile the sense of prosperity and freedom evoked by IBs with a demonstration 
of their relevance to Indonesia's traditional values. Its research recommended adding a "local touch" to the communication materials promoting IBs:

\section{It is accepted that basic marketing appeals (or persuasive themes) are universal. A proper care over local custom and tradition will enhance the communication effectiveness of those "global mission". In other words, whilst the advertising concept can be standardized, deep-rooted local cultural differences seem to necessitate adaptation of the actual advertisements to the mores of smokers in Indonesia. ${ }^{86}$}

Standardised imagery and even names are not always perceived in the same way, and coincidence can transform the local meaning of a global symbol. BATI noted, for example, that the State Express 555 logo resonated with both Indonesian folklore and official ideology:

The name-i.e. 555 as shown on the logo-is considered easy to recall. Some even associate that with the five heroes of the traditional legend (Mahabarata). Quite interestingly, some even try to relate with the five principles of the State (Panca Sila). These phenomena only indicate that its smokers try to make SE 555 as part of their living reality, through adjusting it to the context of their immediate environment ${ }^{65}$

Research for PM identified a similarly fortuitous link for its $\mathrm{L}+\mathrm{M}$ brand, respondents associating it "with 'Lintas Melawai', the street where young Jakartans go cruising/ showing off etc" ${ }^{\prime 66}$

\section{Product development: imitating the kretek}

BAT's willingness to adapt to local context is further demonstrated by its sustained interest in developing clove based products to mimic the distinctive appeal of kreteks. ${ }^{87}$ Several prototypes developed from the late 1970s experimented with differing levels of eugenol (clove oil). Project Variety, for example, aimed to develop a product that would appeal to:

new/younger smokers/-white cigarette smokers dissatisfied with product attributes-flavour amplitudes etc./Kretek smokers who find clove impact too strong. ${ }^{88} 89$

Such experiments culminated in the launch of ultimately unsuccessful brands. These included Ventura, which "had a perceptible clove taste but was insipid relative to full kreteks", and Citra, the failure of which was "attributed by some people to the low clove character and western base blend style" ${ }^{\prime 90}$

Both local and global factors exacerbated the product development difficulties confronting BATI. Locally, the protection offered to the kretek industry incorporated a ban on foreign owed companies manufacturing similar clove based products. ${ }^{91}$ Despite earlier encouragement from the Minister of Finance, ${ }^{878}$ an application to produce clove cigarettes in Semerang and Cirebon ${ }^{92}$ was rejected. The company then sought "a potential partner in Indonesia with whom to propose a joint venture in the manufacture of Kreteks", identifying Liem Sioe Liong as a likely candidate. ${ }^{93}$ Liong's perceived suitability reflected his status as head of the Salim Group and his close business relationship with President Suharto. Amid the cronyism of Suharto's Indonesia this could be hugely important, particularly given Liong's reported ownership of an import licenses for cloves. ${ }^{94}$
BAT's proposed development of a kretek-like product in Indonesia held potentially global ramifications, with divided opinions on the scheme's merits. While the local commercial logic for developing such a product seemed clear, there was concern that it could expose BAT to significant risks. The toxicity of eugenol and the high tar and nicotine yields of clove-based cigarettes posed a dilemma, since to compete with mainstream kreteks BAT would have to contravene international guidelines for eugenol intake. ${ }^{95}$ This was neatly summarised by Geoff Brooks of BAT's product development and marketing department:

If we exceed the levels quoted by Western authorities we leave ourselves open to criticism for double standards. If we do not follow the Kretek trend we run the risk of losing market share. If we use the recommended levels of eugenol we may not attract Kretek smokers. ${ }^{94}$

While BATI were enthusiastically proceeding with a comparatively high eugenol content, ${ }^{96} \mathrm{BAT}^{\prime} \mathrm{S}$ R\&D co-ordinator $\mathrm{Al}$ Heard stressed that such a product could both "attract adverse comment that will be difficult or impossible to refute" and present an easy target for litigation. ${ }^{97}$ Such concerns were heightened as US research demonstrated that "eugenol is more toxic by inhalation than by ingestion". ${ }^{98}$

BAT seemingly chose to prioritise such global concerns, establishing that the total tar delivery from development products should not exceed that of its major local brand Commodore LS. ${ }^{99}$ Citra was ultimately withdrawn "due to concerns about the materials used and some political repercussions", ${ }^{100}$ though the company remained interested in exploring such products at least through to 1993.

\section{DISCUSSION}

This analysis of the difficulties encountered by TTCs in Indonesia serves as a counterweight to simplistic depictions of the global expansion of TTCs as inexorable. The distinctive experience of the TTCs in Indonesia also illustrates that globalisation cannot be understood as simply a process foisted on to developing countries by transnational corporations. Global change can be mediated by local institutions, norms and actors, requiring significant local adaptation in the pursuit of corporate objectives.

Indonesia has not been untouched by the globalisation of the tobacco industry. The global trend towards increased consumption of light brands, for example, has been given a distinctive twist via the emergence of "light kreteks" that now account for around $10 \%$ of the total kretek market. ${ }^{29}$ In addition to the localisation of global actors, it is important to recognise the globalisation of local actors. The kretek manufacturers should not be dismissed as marginal players destined for obsolescence, and the commercial opportunities provided by global change are not necessarily confined to TTCs. PT Djarum, for example, is sublicensing brands to a Brazilian manufacturer, is the leader in the growing kretek market in the USA, strong in Malaysia and Singapore and targeting progress in Europe. Djarum's head of international sales attributes such success to a "globalisation effect" by which people are "more open to thinking about foreign products". ${ }^{101}$ The interest of TTCs in Indonesia can also constitute a resource for the kretek industry, with Gudang Garam agreeing a deal to distribute Imperial's international brands West and Davidoff ${ }^{102}$ and Sampoerna entered into a joint venture with Gallaher in Malaysia. ${ }^{103}$

Such expansion, ongoing domestic dominance of the huge market, and the protection of successive Indonesian governments suggests that the kretek industry merits greater attention from health advocates both nationally and globally. 


\section{What this paper adds}

Tobacco consumption in Indonesia is predominantly by kreteks, clove based cigarettes. TCs have so far been unable to make substantial progress in this key target market.

This is the first analysis of industry documents focused on Indonesia. In explaining the difficulties encountered by TTCs it enables a more advanced understanding of the global tobacco industry and highlights challenges confronting tobacco control in Indonesia.

Indonesia's delegation to the Framework Convention on Tobacco Control noted that "the aggressive marketing practices of the transnational tobacco companies threaten the health, and ultimately the lives, of our people". ${ }^{104}$ The kretek industry amply demonstrates that aggressive marketing practices are not confined to the TTCs, ${ }^{3267}$ while the Indonesian government's support of kretek manufacturers constitutes a serious threat to the health of its people. The Minister of Industry and Trade, Rini Suwandi, reportedly delayed signing the World Health Organization's Framework Convention on Tobacco, fearing its impact on the kretek industry. ${ }^{105}$

This is not to suggest that the TTCs will remain confined to their current market share, and they can reasonably be considered an escalating threat to public health in Indonesia. Some indications suggest that in the post-Suharto Indonesia TTCs are asserting more effective political influence. Recent changes to the excise system appear to have been comparatively favourable to TTCs. ${ }^{30}{ }^{106}$ White cigarette manufacturers also apparently scored a notable legislative victory with the passage of legislation imposing lower limits on tar and nicotine yields. ${ }^{29}{ }^{107}$ Given the higher yields associated with eugenol, this provides a new marketing opportunity for TTCs in competing with kreteks. BATI has long contemplated using the "numbers game"108 to gain competitive advantage against kreteks and recent press advertisements have exploited this disparity. Most disturbingly, TTCs seem well placed to expand smoking prevalence among Indonesian women. White cigarettes are disproportionately popular among female smokers ${ }^{109}$ and this could constitute a significant driver in the trajectory of Indonesia's tobacco epidemic.

\section{ACKNOWLEDGEMENTS}

This work was supported by NIH grant R01 CA091021-03 "Globalization, the Tobacco Industry and Policy Influence".

Documents cited in this paper not currently available on existing websites will be posted on the Tobacco Control Research page on the London School of Hygiene and Tropical Medicine website http:// www.lshtm.ac.uk/cgch/tobacco/index.html.

\section{Authors' affiliations \\ S Lawrence, J Collin, Centre on Global Change and Health, London School of Hygiene \& Tropical Medicine, London, UK}

\section{REFERENCES}

1 Gajalakshmi CK, Jha P, Ranson K, et al. Global patterns of smoking and smoking-attributable mortality. In: Jha P, Chaloupka F, eds. Tobacco control in developing countries. Oxford: Oxford University Press, 2000:11-39.

2 Mackay J, Eriksen M. The tobacco atlas. Geneva: World Health Organization, 2002.

3 World Health Organization. The world health report 2002: reducing risks, extending healthy life. Geneva: World Health Organization, 2002.

4 Yach D, Bettcher D. Globalisation of tobacco industry influence and new global responses. Tobacco Control 2000;9:206-16.

5 Bettcher D, Yach D, Guindon E. Global trade and health: key linkages and future challenges. Bull World Health Organ 2000;78:521-34.
6 Collin J. Think global, smoke local: transnational tobacco companies and cognitive globalisation. In: Lee K, ed. Globalization and health: case studies. London: Palgrave, 2002.

7 Yach D. WHO consultation on litigation and public inquiries as public health tools for tobacco control, 2001. http://www5.who.int/tobacco/ page. $\mathrm{cfm}$ ? $\mathrm{td}=193$ [Accessed 4 May 2003).

8 Joosens L, Ritthiphakde B. Role of multinationals and other private actors: trade and investment practices. Paper presented to the WHO International Conference on Global Tobacco Control Law: Towards a WHO Framework Convention on Tobacco Control, New Delhi, 7-9 January, 2000.

9 Hammond R. Consolidation in the tobacco industry. Tobacco Control 1998;7:426-8.

10 Collin J, Lee K. The United Kingdom, globalisation and transborder health risk. London: The Nuffield Trust (forthcoming).

11 Tobacco Journal International. Global tobacco: Where cigarette manufacturers roam. November 2001. http://www.tobaccojournal.com/ show_artikel.php3?id = 2321 \&banner $=$ rentsch.

12 Crescenti M. The New Tobacco World. Tobacco Journal International 1999 March:51-53.

13 Chaloupka F, Laixuthai A. US Trade Policy and Cigarette Smoking in Asia, Working Paper No.5543. Cambridge, Massachusetts: National Bureau of Economic Research, 1996.

14 Weissman R, White A. Needless Harm: International Monetary Fund support for tobacco privatization and for tobacco tax and tariff production, and the cost to public health. Washington: Essential Action, September 2002. http:// www.essentialaction.org/needlessharm.pdf.

15 Glantz S. The truth about big tobacco in its own words. BMJ 2000;321:313-14.

16 Committee of Experts. Tobacco company strategies to undermine tobacco control activities at the World Health Organization. Geneva: WHO, July 2000.

17 Stebbins K. Going like gangbusters: transnational tobacco companies "making a killing" in South America. Medical Anthropology Quarterly 2001; 15:147-70.

18 MacKenzie R, Collin J, Lee K. The tobacco industry documents: an introductory handbook and resource guide for researchers. London: London School of Hygiene \& Tropical Medicine, 2003. http://www.Ishtm.ac.uk/ cgch/tobacco/Handbook\%2008.07.03.pdf [Accessed 5 July 2004).

19 Bero L. Implications of the tobacco industry documents for public health and policy. Ann Rev Public Health 2003;24:267-88

20 Balbach E. Tobacco industry documents: comparing the Minnesota Depository and internet access. Tobacco Control 2002;1 1:68-72.

21 Malone RE, Balbach, eds. Tobacco industry documents: treasure trove or quagmire? Tobacco Control 2000;9:334-8.

22 Collin J, Lee K, Gilmore AB. Unlocking the corporate documents of British American Tobacco: an invaluable global resource needs radically improved access. Lancet 2004;363:1746-7.

23 Muggli ME, LeGresley EM, Hurt RD. Big tobacco is watching: British American Tobacco's surveillance and information concealment at the Guildford depository. Lancet 2000;363:1812-19.

24 Lee K, Gilmore AB, Collin J. Looking inside the tobacco industry: revealing insights from the Guildford Depository. Addiction 2004;99:394.

25 BAT. [Asia Pacific Regional Conference: Strategy Exercise Data Pack]. 5 January 1996. British American Tobacco. Bates No. 503909616. Available from Guildford Depository.

26 World Bank. Indonesia: Curbing the tobacco epidemic, 1999. http:// www1.worldbank.org/tobacco/pdf/country\%20briefs/Indonesia\%20.pdf.

27 Corrao MA, Guindon GE, Sharma N, Shokoohi DF, eds. Tobacco control country profiles. Altanta, Georgia: American Cancer Society, 2000. http:// tobacco.who.int/repository/tld105/Indonesia.pdf.

28 Anon. World tobacco file, 2nd edn. London: DMG Business Media, 1998.

29 Tobacco Journal International. Finding the right measure. 8 October 2002 http://www.tobaccojournal.com/show_artikel.php3?id = 2779\&banner $=$ arista.

30 Van Liemt G. The world tobacco industry: trends and prospects. Geneva: International Labour Office, 2002. http://www.ilo.org/public/english/ dialogue/sector/techmeet/tmets03/tmets-r.pdf; http://www.ilo.org/ public/english/dialogue/sector/papers/tobacco/wp 179.pdf.

31 Hanusz M. Kretek: the culture and heritage of Indonesia's clove cigarettes. Jakarta: Equinox Publishing (Asia), 2002.

32 Reynolds C. The fourth largest market in the world. Tobacco Control 1999:8:89-91.

33 Anon. Delights for the senses: Indonesia's love of kreteks. Tobacco Journal International 29 November 2001.

34 Cox H. The global cigarette: origins and evolution of British American Tobacco 1880-1945. Oxford: Oxford University Press, 2000.

35 Reid A. From betel-chewing to tobacco smoking in Indonesia. Journal of Asian Studies 1985:44:529-47.

36 Cullman H. [An Investment in the Indonesia Cigarette Industry $(\$ 6,725,000)]$. 18 May, 1971. Philip Morris. Bates No. $2012581138-$ 1162. http://legacy.library.ucsf.edu/tid/nea85e00.

37 PM Asia. [Philip Morris Asia Corporate Affairs Plan 1990-1992]. December 1989. Philip Morris. Bates No. 2500048000-4042. http:// legacy.library.ucsf.edu/tid/lil19e00.

38 Pilger J. The new rulers of the world. London: Verso, 2002.

39 BAT. [Meeting of the Committee of Directors held at Westminster House, London]. 18 May 1971. British American Tobacco. Bates No. 2010482878290. http://tobaccodocuments.org/health_canada/2165_004.html.

40 Pangestu $M$. Foreign investment policy: evolution and characteristics. In: lqbal F, James W, eds. Deregulation and development in Indonesia. Praegar Publishers, 2002. 
41 Tarmidi L. Changing structure and competition in the kretek cigarette industry. Bulletin of Indonesian Economic Studies 1996 December; 32:85-107

42 Foucault-Mohammed C. Employment trends in the tobacco sector: challenges and prospects. . Geneva: International Labour Office, 2003. http://www.ilo.org/public/english/dialogue/sector/techmeet/tmets03/ tmets-r.pdf.

43 BATCo [Future Business Environment]. 1982. British American Tobacco. Bates No. 500001673-703. Available from Guildford Depository.

44 Robison R. Indonesia: crisis, oligarchy, and reform. In: Rodan G, Hewison K, Robison R, eds. The political economy of south-east Asia, 2nd ed. Oxford: Oxford University Press, 2001

45 Schwarz A. A nation in waiting: Indonesia's search for stability. Allen \& Unwin, 1999.

46 Kartasasmita G. Indonesia Letter of Intent and Memorandum of Economic and Financial Policies. 29 July 1998 International Monetary Fund 1998. http://www.imf.org/external/np/loi/072998.htm.

47 Sugianto G. [Letter to Sharon Boyse,]1991. British American Tobacco. Bates No: 304046143, Available from Guildford Depository.

48 Sardjono D. [Anti Cigarette Movement: High Tide Waves]. 1993. British American Tobacco. Bates No. 304046106. Available from Guildford Depository.

49 Thompson M. [Report from Michael J Thompson on Visit to Jakarta, The Tobacco Institute of New Zealand]. 1991. British American Tobacco. Bates No. 304046146-153. Available from Guildford Depository.

50 Sardjono D. [P.T. BAT Indonesia, Title: Re, Indonesian forthcoming law on health]. 5 August 1992. British American Tobacco. Bates No: 304046112 Available from Guildford Depository.

51 Sardjono D. [Re: Tobacco classified proposal in a forthcoming law on health]. 1992. British American Tobacco. Bates No. 304046125 . Available from Guildford Depository.

52 Boyse S. [Bali Media Briefing]. 1992. British American Tobacco. Bates No: 304044614-16. Available from Guildford Depository.

53 Boyse S. [Industry Briefing sessions for the Media]. February 1992. British American Tobacco. Bates No: 304046138. Available from Guildford Depository.

54 Sardjono D. [Post Bali Media Briefing]. 1992. British American Tobacco. Bates No. 304044598. Available from Guildford Depository.

55 British American Tobacco. [P.T. BAT Indonesia Company Plan 1992 to 1996]. 1992. British American Tobacco. Bates No. 500001703. Available from Guildford Depository.

56 Tobacco Journal International. Retail prices and excise taxes to rise. 200210-25. http://www.tobaccojournal.com/show_artikel.php3?id = 2814\&banner $=$ itm.

57 BATCo. [Beri Evaluation of Investment Prospects in SE Asia]. No date. British American Tobacco. Bates No: 303665969, Available from Guildford Depository.

58 British American Tobacco. [Future Business Report]. 1991. British American Tobacco. Bates No. 500001673-1713. Available from Guildford Depository.

59 Tobacco Executive Committee. [BAT Indonesia Company Plan Discussion 1993-1997]. 1993. British American Tobacco. Bates No. 500196928-32. Available from Guildford Depository.

60 Priem J. [General Manager's Monthly Review].1993. British American Tobacco. Bates No. 500196895. Available from Guildford Depository.

61 Webb W. [Board Presentation-Asia/Australia Overview]. 1998. Philip Morris. http://legacy.library.ucsf.edu/tid/cml19e00 [Accessed 3 Aug 2003].

62 Cunningham R. Smoke and mirrors: the Canadian tobacco war. Ottawa: International Development Research Centre, 1996.

63 Frankel G. U.S. Aided Cigarette Firms in Conquests Across Asia. Washington Post. 17 November 1996. http://www.washingtonpost.com/ wp-rv/national/longterm/tobacco/stories/asia.htm [Accessed 2 Aug 2001).

64 Dreyfus R. Big Tobacco Rides East. MOJOwire magazine, January/ February 1999. http://www.motherjones.com/mother_jones/JF99/ dreyfuss.html [Accessed 11 Aug 2001)

65 BATCo. [Lucky Strike Sponsorship]. 1993. British American Tobacco. Bates No.303593886-900. http://www.library.ucsf.edu/tobacco/batco/html/ 500/560/otherpages/allpages.html.

66 BAT Indonesia. [A study on the smokers of International Brands]. No date. British American Tobacco. Bates No. 400458940. Available from Guildford Depository..

67 Survey Research Indonesia. [Presentation of Findings of Qualitative Project-Evaluation of Suitability of four brands for Indonesian Market]. 1988 April. Philip Morris. http://legacy.library.ucsf.edu/tid/cey32e00

68 Pollay R, Dewhirst T. Marketing cigarettes with low machine-measured yields. In: National Cancer Institute. Risks associated with smoking cigarettes with low machine-measured yields of tar and nicotine. Smoking and Tobacco Control Monograph 13, Bethesda, Maryland: US Department of Health and Human Services, 2001.

69 Ideal World Productions. To die for: cigarettes. UK broadcast 2 Dec 2002, Channel 4.

70 Rembiszewski J. ['Think Global-Act Global-Adapt Local', Speech, BSB Dorland Annual conference]. 1992. British American Tobacco. Bates No: 500062031-62040, accessed via TDO, Document 03300623, http:// tobaccodocuments.org/health_canada/03300623.

71 Svensson G. "Glocalization" of business activities: a "glocal strategy" approach. Management Decision 2001;39:6-18.

72 Wind $Y$. The myth of globalization. The Journal of Consumer Marketing $1986 ; 3(2): 23-6$.
73 Resnik F. [Remarks by Frank E Resnik, Chairman, Philip Morris U.S.A, Junior Chamber International Annual Conference] 7/11/1989. Philip Morris. Bates No. 2025849885-9945. http://legacy.library.ucsf.edu/tid/ cin $14 \mathrm{e} 00$.

74 Keim T. [Memo to S. Dabholkar, Subject-Research Questions]. 19/07/ 1988. Philip Morris. Bates No. 2504054648. http:// legacy. library.ucsf.edu/cgi/getdoc?tid = ahy32e00\&fmt = tif\&ref = results.

75 Berghoff L. [Re: Marlboro Indonesia TVC edits Letter to L Greher]. 24/06/ 1992. Philip Morris. Bates No. 2500138351-8352. http:// legacy.library.ucsf.edu/tid/bkc42e00.

76 Kluger A. Ashes to sshes: America's hundred-year war, the public health, and the unabashed triumph of Philip Morris. New York: Alfred A Knopf, 1996.

77 Sardjono D. [Letter to D. Bacon]. 28/6/1993. British American Tobacco. Bates No. 304046016 . Available from Guildford Depository.

78 Boyse S. [Letter to D Sarjono] 4/3/1993. British American Tobacco. Bates No. 304046090 . Available from Guildford Depository.

79 Bacon D. [Letter to D Sarjono] 25/06/1993. British American Tobacco. Bates No: 304046019, Available from Guildford Depository.

80 Kaufman NJ, Nichter $M$. The marketing of tobacco to women: global perspectives. In: Samet J, Yoon SY, eds. Women and the tobacco epidemic: challenges for the 21 st Century. Geneva: WHO, 2001:69-98.

81 Fincher N. [Re: Philip Morris Research]. 5/02/88. Philip Morris, Bates No.2504054604. [Accessed Nov 2002]

82 EMRO. Voice of Truth, vol 2. World Health Organization Regional Office for the Eastern Mediterranean 2001. http://www.emro.who.int/TFI/ VoiceOfTruthVol2.pdf [Accessed 14 Aug 2001]

83 Rahman D. [Public Affairs Report for the month of February 1995]. 1995. British American Tobacco. Bates No. 502592920. Available from Guildford Depository.

84 Creighton DE. [Alternatives to Kretek Cigarettes]. 5 December 1979. British American Tobacco. Bates No. 102421570-576. Available from Guildford Depository.

85 Islam Online. Indonesian Muslim Body Launches Cigarette Brand. 12 January 2003. http://www.islam-online.net/english/news/2003-01/12/ article 15.shtml [Accessed 19 July 2003]

86 BAT Indonesia. [A study on the smokers of International Brands] No date. British American Tobacco. Bates No. 400458940. Available from Guildford Depository.

87 Grime D. [Letter to the Chemist at Product Development Laboratory at BAT Ltd.]. March 1979. British American Tobacco. Bates No.102421463. Available from Guildford Depository.

88 Marjoram M, Leonard R, Koerdi $\mathrm{H}$, et al. [Notes of Meeting Friday $22^{\text {nd }}$ July 1983 on Indonesia- Alternative Product Opportunities] 22/07/1983. British American Tobacco. Bates No.102421652. Available from Guildford Depository.

89 Marjoram M. [Tobacco Executive Committee]. April 1981. British American Tobacco. Bates No.109878917. Available from Guildford Depository.

90 British American Tobacco Indonesia. [Draft-Indonesia: Developments Under Projects Batik/Variety]. No date. Bates No. 103135288-89. Available from Guildford Depository.

91 Roberts P. [Indonesia-Alternative Strategy]. 13/07/1983. British American Tobacco. Bates No.10241 1556. Available from Guildford Depository.

92 EsmerkInformation. [Indonesia: BAT to Produce Clove Cigarettes?]. 7/9/ 1985. British American Tobacco. Bates No. 100659424. Available from Guildford Depository.

93 Carraway B. [Letter from BP Carraway to A. Bruell re: Liem Sioe Liong] 14/ 11/1984, British American Tobacco. Microfiche- No Bates assigned. Available from Guildford Depository.

94 Goldstein C, Dorosario L, Schwarz A, et al. [Far Eastern Economic Review Asia] 29 Mar 1990. Bates No: TIMN0016458-TIMN0016464. http:// tobaccodocuments.org/ti/TIMN0016458-6464.html.

95 Brooks G. [Clove oil/eugenol]. 19/04/81 British American Tobacco. Bates: 102411709-11. Available from Guildford Depository.

96 Territorial Director. [Note for the Tobacco Executive Committee]. April 1981. British American Tobacco. Bates No. 109878921. Available from Guildford Depository.

97 Heard A. [Confidential Note: Eugenol and Cloves] April 1985. British American Tobacco. Bates No.109878769. Available from Guildford Depository.

98 Mitchell T. [Strictly Confidential: Clove-Containing Cigarettes] May 1986. British American Tobacco. Bates No: 103135590-91, Available from Guildford Depository.

99 Jenkins C. [Indonesian Exercise] April 1987. British American Tobacco. Bates No: 400322900. Available from Guildford Depository.

100 Jenkins C. [Letter from C. Jenkins to Ng Beng Sim] Oct. 1993. British American Tobacco. Bates No: 400896099, Available from Guildford Depository.

101 Anon. Diarum expands. Tobacco Reporter October 2002. http:// www.tobaccoreporter.com/backissues/Oct2002/storyl .asp.

102 Anon. Packing for the Far East. Tobacco Journal International Dec 2002. http://www.tobaccojournal.com/show_artikel.php3?id = 2877\&banner $=$ siemens.

103 Anon. Gallaher announces joint venture with Sampoerna International. Tobacco Journal International 4 April 2002. http:// www.tobaccojournal.com/show_artikel.php3?id = 2527\&banner $=$ siemens

104 Permanent Mission of the Republic of Indonesia. Statement by the delegation of the Republic of Indonesia to the first meeting of the 
Intergovernmental Negotiating Body on the WHO Framework Convention on Tobacco Control. Geneva, 17 October 2000. http://www3.itu.int/ MISSIONS/Indonesia/state/st01017bako.htm.

105 Anon. Minister wants delay on FCTC ratification. The Jakarta Post June 2004. http://www.tobacco.org/articles/country/indonesia/.

106 Anon. BAT Indonesia Reports 2002 Earnings. Bloomberg News 18 March 2003. http://www.tobacco.org/news/120183.html.
107 Moore M. Tobacco controls vanish in a puff of smoke. The Age 17 March 2003. http://www.theage.com.au/articles/2003/03/17/ 1047749718162.html?oneclick = true.

108 Leonard R. [Project BATIK]. 21/10/1981. British American Tobacco. Bates No: 102411661 , Available from Guildford Depository.

109 Anon. Smokers in Indonesia. Daily Research News Online 7 May 2003. http://www.mrons.com/drno/news2248.htm. 